\title{
The Wound Infection Following Caesarean Section
}

Dr. Begum Shamsun Naher Shirin ${ }^{1 *}$, Dr. Rawshan Ara Khanam², Dr. Sheikh Firoz Kabir ${ }^{3}$, Dr. Sabina Parveen ${ }^{4}$, Dr. Binoy Krishna Golder ${ }^{5}$, Dr. Fatema Ruhane ${ }^{6}$

${ }^{1}$ Associate Professor, Current Charge, Gynae, US Bangla Medical College, Dhaka, Bangladesh

${ }^{2}$ Professor, Gynae, US Bangla Medical College, Dhaka, Bangladesh

${ }^{3}$ Professor, General and Laparoscopic Surgeon, Principal of US Bangla Medical College Hospital, Dhaka, Bangladesh

${ }^{4}$ Assistant Professor, Gynae, US Bangla Medical College, Dhaka, Bangladesh

${ }^{5}$ DGO, Assistant Professor, Department of Gynae, Patuakhali Medical College, Patuakhali, Bangladesh

${ }^{6} \mathrm{HMO}$, Mugda Medical College and Hospital, Dhaka, Bangladesh

DOI: $\underline{10.36347 / \text { sjams.2020.v08i11.041 }}$

| Received: 12.10 .2020 | Accepted: 26.10.2020 | Published: 28.11.2020

*Corresponding author: Dr. Begum Shamsun Naher Shirin

Abstract

Original Research Article

Objective: In this study our main objective is to evaluate the wound infection following caesarean section. Method: This cross-sectional study was done at Department of Obstetrics \& Gynaecology in tertiary Medical College Hospital from July 2018 December 2019. Where 98 patients who develop wound infection after caesarean section in the study period was taken as case. Another 100 patients were taken as control. Result: During the study maximum patients in case $(17.3 \%)$ and control $(15 \%)$ group belong to age group 20 to 24 years and among 1050 caesarean section 98(9.33\%) patients develop wound infection. Also 97 case group patients and 95 control group faced emergency operation. Conclusion: After many examinations we can conclude that all pregnant women should have ante natal check up by trained personals also they need Health education. Further study is needed for better outcome.

Keywords: Wound infection, cesarean delivery, bacteria.

Copyright $(\mathcal{C} 2020$ The Author(s): This is an open-access article distributed under the terms of the Creative Commons Attribution 4.0 International License (CC BY-NC 4.0) which permits unrestricted use, distribution, and reproduction in any medium for non-commercial use provided the original author and source are credited.

\section{INTRODUCTION}

Caesarean section is a major abdominal surgery and most common operation done by obstetrician. The past several decades have seen an increase in the incidence of caesarean section. The WHO estimates the caesarean section at between 10$15 \%$ of all births in developed countries. Reports indicated a range of 18 to $83 \%$ in the incidence of postoperative infectious complication where prophylactic antibiotics have not been utilized." Wound infection has been reported in 2-16\% of all women who have caesarean

Infection increases the discomfort and disability experienced by patients following surgical procedure including caesarean section and in their most severe form may endanger life. The main determinants of infection are the Virulence of microorganisms, the host defense mechanism and the environment and there is continuous interaction between these three factors. Wound infection results from bacterial contamination of the wound. Infection rate is proportionate to number of bacteria, type of bacteria, incision involving mucous surface and the site of existing infection in the body.

In caesarean section the source of infecting organism may be, endogenous from the patient, contamination from the air in the operation theatre and direct such as from the punctured gloves. The following risk factors predispose to subsequent wound infection in women undergoing caesarean section - obesity, diabetes, prolonged hospitalization before caesarean section, prolonged rupture of the membrane, chorioamnionitis, endomyometritis, prolonged labour, emergency rather than elective indications for caesarean section and anemia. Infection and breakdown of wounds are also results of poor surgical technique (dead. space, hematoma) [1, 2]. 

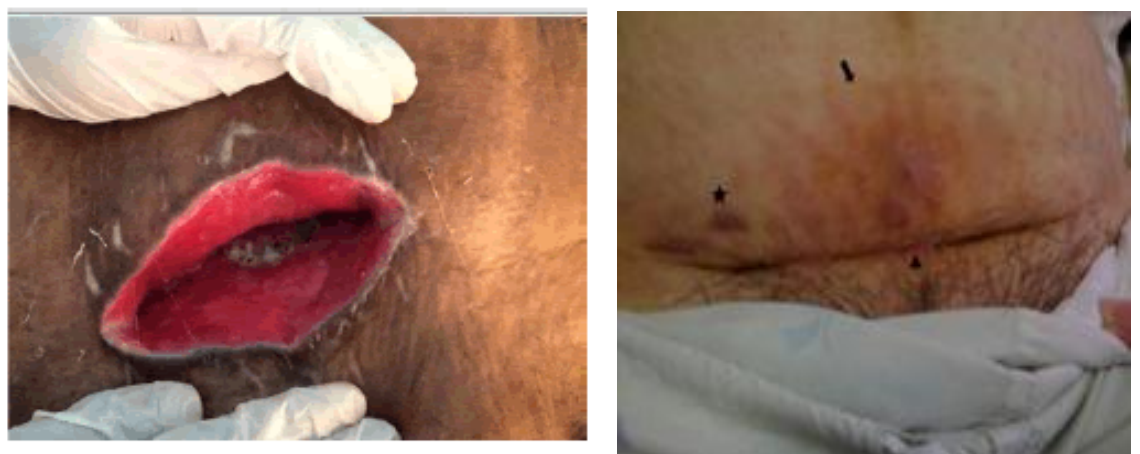

Fig 1a and 1b: Wound infection after caesarean section [3]

Usually post-operative wound infection appears between 3rd to 5th post-operative days but it may appear as early as in the 1" day of operation and even after the patient has left the hospital, Classically the presence of post-operative wound infection has been confirmed by documenting the typical clinical signs of inflammation along with drainage of purulent or culture positive material from the wound.

The organism responsible for most postcaesarean section wound infection originates on the patients' skin. Staphylococcus aureus is the organism most commonly isolated. Streptococcus species, E. coli and other Gram-negative organisms that may originally have colonized the amniotic cavity are also seen. Occasionally Bacteroids which comes only from the genital tract, is isolated from material taken from serious wound infection.

Early diagnosis of wound infection by clinical features and their treatment according to the culture and sensitivity report of wound swab/discharge can reduce the morbidity and mortality due to wound infection [4]. In this study our main objective is to evaluate the wound infection following caesarean section.

\section{OBJECTIVE \\ General Objective}

- To evaluate wound infection following caesarean section, risk factors, causative organisms and an sensitivity of wound infection following caesarean section.

\section{Specific Objective}

- To evaluate the incidence of wound infection during the study period

- To detect the risk factors associated with wound infection following caesarean section

- To identify the causative organisms responsible for wound infection.

- To find out appropriate antibiotic by culture \& sensitivity test of wound swab in RMCH.

\section{Methodology Study Type} of study.

This study was a descriptive observational type

\section{Place and Period of Study}

- This study was conducted at Department of Obstetrics \& Gynaecology in Tertiary Medical College Hospital from July 2018 December 2019.

\section{Sample Size and Sampling Technique}

- All the 98 patients who develop wound infection after caesarean section in the study period was taken as case. Another 100 patients were taken as control by purposively random sampling technique who had undergone caesarean section but did not develop wound infection.

\section{Inclusion Criteria}

- Patients having wound infection after caesarean section.

\section{Exclusion Criteria}

- Presence of lower abdominal skin infection.

- Another procedure with caesarean section (e.g. BLTL).

- Patients on immune suppressant drugs.

\section{METHOD}

Informed consent was taken from all the patients under study. In the study period 98 patients developed signs of post cesarean section wound infection. The Centre for Disease Control National Nosocomial Infections Surveillance System (CDC NNIS) definition was followed to define surgical site infection. Another 100 patient was also observed and taken as control who had undergone caesarean section but did not develop wound infection. All relevant datademographic information \& information related to pregnancy, labour \& operation was recorded. Discharge from the wound was send for culture and sensitivity test. All patient was followed till the wound healing and 
discharge from hospital. Nine risk factors were studied as independent variable for wound infection.

\section{Statistical Analysis}

Data was collected in standardized data collection form. Body mass index was measured on 3 post-operative day. Patients with BMI less than $19 \mathrm{~kg} / \mathrm{m}^{2}$ was considered malnourished and patients with $\mathrm{BMI}>30 \mathrm{~kg} / \mathrm{m}^{2}$ was considered obese. Minimum four antenatal visits were considered as regular antenatal checkup. Duration of labour pain for more than 24 hours was considered as prolongedlabor. Statistical analysis was done using SPSS software. To test the significance of association between risk factor and wound infection the univariate analysis was done using the Chi-square test.

\section{RESULT}

In Figure-2 shows age distribution of the patients where maximum patients in case $(17.3 \%)$ and control (15\%) group belong to age group 20 to 24 years. The following figure is given below in detail:

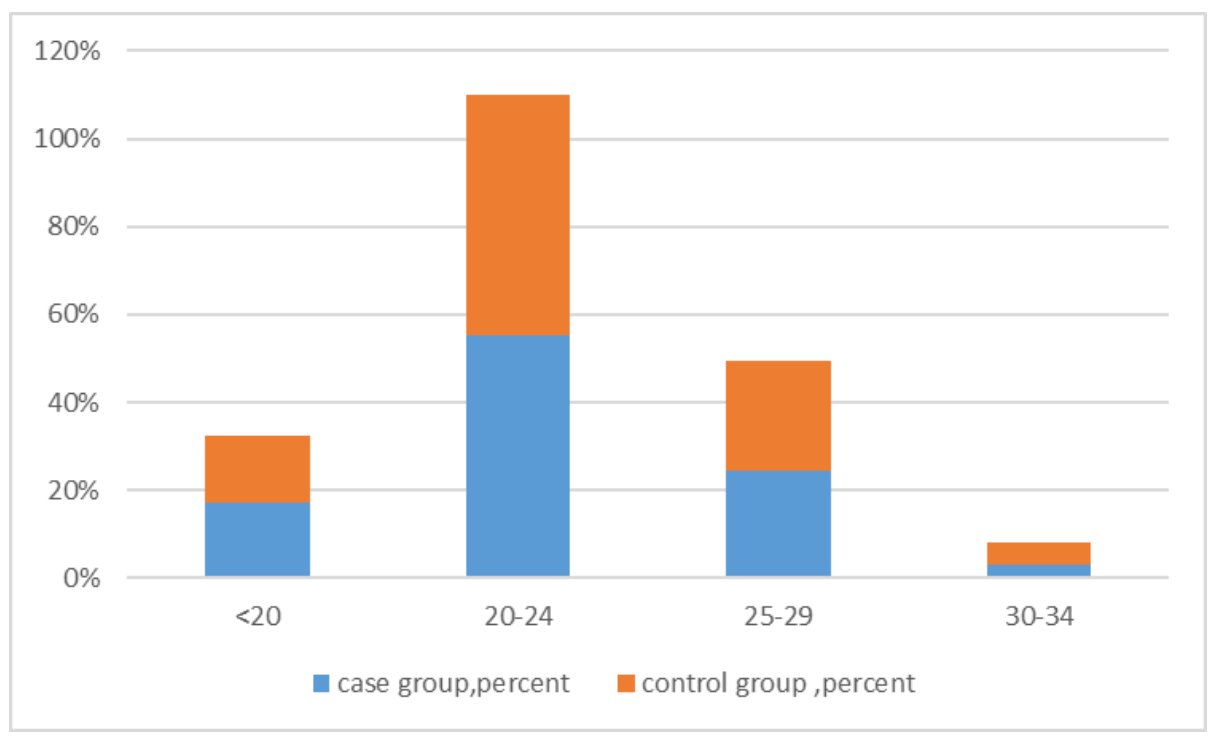

Fig-2: Age distribution of the patients

In Table-1 shows height, Scio demographic condition and gravidity of the patients where majority $77(78.6 \%)$ and $65(65 \%)$ in case and control group respectively patient came from middle class family. Regarding height maximum number of women of both case $78(79.6 \%)$ and control $82(82 \%)$ belongs to height
$151-154 \mathrm{~cm}$. Most of the patients was primigravida $80(81.6 \%)$ in case group and $85(85 \%)$ in control group respectively. There was no significant difference between case and control group in particulars of the patients. The following table is given below in detail:

Table-1: Scio demographic condition and gravidity of the patients

\begin{tabular}{|l|l|l|l|l|}
\hline \multirow{2}{*}{ Variable } & \multicolumn{2}{|l|}{ Case } & \multicolumn{2}{l|}{ Control } \\
\cline { 2 - 5 } & n & \% & \multicolumn{1}{l|}{ n } & $\%$ \\
\hline Socio-demographic condition \\
\hline Middle class & 77 & 78.6 & 65 & 65.0 \\
\hline Lower class & 18 & 18.4 & 34 & 34.0 \\
\hline Upper class & 3 & 3.0 & 1 & 1.0 \\
\hline Height & & & & \\
\hline $150 \mathrm{~cm}$ less & 6 & 6.1 & 5 & 5.0 \\
\hline $151-154 \mathrm{~cm}$ & 78 & 79.6 & 82 & 82.0 \\
\hline $155-156 \mathrm{~cm}$ & 14 & 14.3 & 13 & 13.0 \\
\hline Gravida & & & & \\
\hline Multigravida & 18 & 18.4 & 15 & 15.0 \\
\hline Primigravida & 80 & 81.6 & 85 & 85.0 \\
\hline
\end{tabular}

In Figure-3 shows incidence of caesarean section in $\mathrm{RMCH}$ where in the study period 4200 delivery were conducted in RMCH. Among them 1050
(25\%) baby were delivered caesarean. The following figure is given below in detail: 


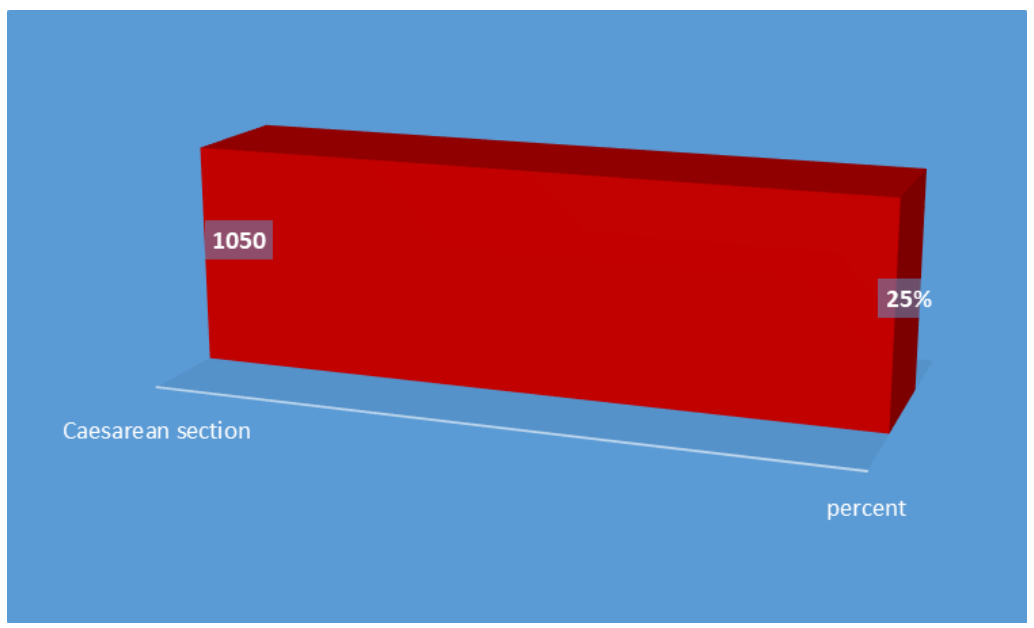

Fig-3: Incidence of caesarean section in RMCH

In Figure-4 showsincidence of wound infection following caesarean section wheretotal of 1050 caesarean section were don in $\mathrm{RMCH}$ in the study period. Among them $98(9.33 \%)$ patients develop wound infection.

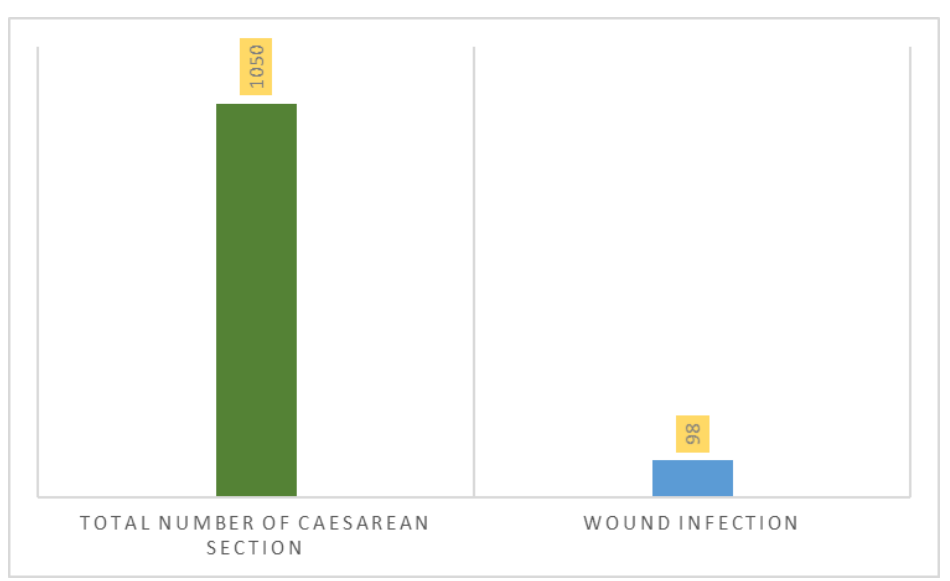

Fig-4: Incidence of wound infection following caesarean section

In Table-2 shows wound infection in emergency versus elective procedure where among 198 patients 97 case group patients and 95 control group faced emergency operation. Following table is given below in detail:

Table-2: Wound infection in emergency versus elective procedure

\begin{tabular}{|l|l|l|l|}
\hline Group & Emergency operation & Elective operation & Total \\
\hline Case (Developed wound infection) & 97 & 1 & 98 \\
\hline Control (no wound infection) & 95 & 5 & 100 \\
\hline Total & 192 & 6 & 198 \\
\hline
\end{tabular}

Observed values $(\mathrm{O})$ are shown in table.

So, expected value (E) of number of emergency operation in case group

$$
\begin{aligned}
& =\frac{\text { Row total } x \text { Column total }}{\text { Grand total }} \\
& =(98 \times 192) / 198 \\
& =95.53
\end{aligned}
$$

Expected value of number of elective operation in case group

$$
\begin{aligned}
& =\frac{\text { Row total } X \text { column }}{\text { Gramd expected }} \\
& =(100 \mathrm{X} \mathrm{192}) / 198 \\
& =97.47
\end{aligned}
$$

Expected value (E) of number of elective operations in control group

$$
\begin{aligned}
& =\frac{\text { Row total X Column }}{\text { Grand expected }} \\
& =(100 \mathrm{X} 6) / 198 \\
& =2.53
\end{aligned}
$$


From above calculation we found that Chisquare test value 5 indicates $\mathrm{p}$ value is less than 0.05 . Thus, significant difference is observed between emergency and elective procedure in post cesarean section wound infection rate. The following table is given below in detail:

\begin{tabular}{|l|l|l|l|l|}
\hline Group & Emergency operation & Elective operation & Total \\
\hline \multirow{3}{*}{ Case } & Expected value (E) & 97 & 1 & \multirow{2}{*}{98} \\
\cline { 2 - 4 } & Observed Value (O) & 95.33 & 2.47 & \\
\hline \multirow{2}{*}{ Control } & Observed value (O) & 95 & 5 & \multirow{2}{*}{100} \\
\cline { 2 - 4 } & Expected value (E) & 97.47 & 2.53 & 198 \\
\hline \multirow{2}{*}{ Total } & 192 & 6 & \\
\hline
\end{tabular}

$$
\begin{aligned}
\text { So chi-square } & \left(\mathrm{x}^{2}\right)=\sum \frac{(O-E) 2}{E} \\
& =(97-95.53)^{2} / 95.53+(1-2.47)^{2} / 2.47+(95-97.47)^{2} / 97.47+(5-2.53) / 2.53 \\
& =5
\end{aligned}
$$

$$
\begin{aligned}
\text { Here degree of freedom } & =(\text { row }-1) X(\text { Column }-1) \\
& =(2-1) X(2-1) \\
& =1
\end{aligned}
$$

In Table-3 shows relationship of glycemic status of patients and post section caesarean section wound infection where Chi-square test value 4.91 indicates $\mathrm{p}$ value is less than 0.05 . Thus, significant difference is observed between diabetic and nondiabetic patient in post caesarean section wound infection rate. The following table is given below in detail:

Table-3: Relationship of glycemic status of patients and post section caesarean section wound infection

\begin{tabular}{|l|l|l|l|l|l|}
\hline Group & Hyperglycemic & Euglycemic & Total & The Chi square test value \\
\hline \multirow{3}{*}{ Case } & Observed value (O) & 9 & 89 & \multirow{2}{*}{98} & \\
\cline { 2 - 4 } & Expected Value (E) & 5.44 & $92-56$ & & \\
\hline \multirow{3}{*}{ Control } & Observed Value (O) & 2 & 98 & \multirow{3}{*}{100} & \multirow{3}{*}{4.91} \\
\cline { 2 - 4 } & Expected Value (E) & 5.56 & 94.44 & & \\
\hline Total & 11 & 187 & 198 & \\
\hline
\end{tabular}

Here degree of freedom $=($ row -1$) \times($ Column -1$)$

$$
=(2-1) \times(2-1)
$$$$
=1
$$

In Table-4 shows relationship of Antenatal checkup and post caesarean section wound infection where Chi-square test value 6.01 indicates $p$ value is

\begin{tabular}{|c|c|c|c|c|c|}
\hline \multirow{2}{*}{\multicolumn{2}{|c|}{ Groups }} & \multicolumn{2}{|c|}{ Antenatal check up } & \multirow{3}{*}{$\begin{array}{l}\text { Total } \\
98 \\
\end{array}$} & Chi-square test value \\
\hline & & Regular & Irregular/not taken & & \multirow{6}{*}{6.01} \\
\hline \multirow[t]{2}{*}{ Case } & Observed value $(\mathrm{O})$ & 25 & 73 & & \\
\hline & Expected value (e) & 33.16 & 64.83 & & \\
\hline \multirow[t]{3}{*}{ Control } & Observed value (e) & 42 & 58 & 100 & \\
\hline & Expected value (e) & 33.83 & 66.16 & & \\
\hline & Total & 67 & 131 & 198 & \\
\hline
\end{tabular}

less than 0.05 . Thus significant difference is observed between patients who had taken regular antenatal checkup and those who did not taken ANC in post caesarean section wound infection rate. The following table is given below in detail:

Table-4: Relationship of Antenatal checkup and post caesarean section wound infection.

Here degree of freedom $=($ row -1$) X($ Column -1$)$

$$
\begin{aligned}
& =(2-1) \times(2-1) \\
& =1
\end{aligned}
$$

In Table-5 shows nutritional status and post caesarean section wound infection where Chi-square test value 2.8 indicates $p$ value is more than 0.05 . Thus, in this study, nutritional abnormality is not significantly associated with wound infection rate. The following table is given below in detail: 
Table-5: Nutritional status and post caesarean section wound infection

\begin{tabular}{|c|c|c|c|c|c|c|}
\hline \multirow{2}{*}{\multicolumn{2}{|c|}{ Groups }} & \multicolumn{3}{|c|}{ Nutritional Status } & \multirow[t]{2}{*}{ Total } & \multirow[t]{2}{*}{ Chi-square test value } \\
\hline & & Malnourished & Healthy & Obese & & \\
\hline \multirow[t]{2}{*}{ Case } & Observed value $(\mathrm{O})$ & 12 & 80 & 6 & 98 & \multirow[t]{5}{*}{2.8} \\
\hline & Expected value (e) & 8.9 & 81.6 & 7.4 & & \\
\hline \multirow[t]{3}{*}{ Control } & Observed value $(\mathrm{O})$ & 6 & 85 & 9 & 100 & \\
\hline & Expected value (e) & 9.1 & 81.6 & 7.5 & & \\
\hline & Total & 18 & 165 & 15 & 198 & \\
\hline
\end{tabular}

Here degree of freedom $=($ row -1$) \times($ Column -1$)$

$$
\begin{aligned}
& =(2-1) \times(3-1) \\
& =2
\end{aligned}
$$

In Table-6 shows relationship of anaemia with post-operative wound infection where Chi-square test value 5.2 indicates $\mathrm{p}$ value is less than 0.05 . Thus post caesarean section wound infection rate is significantly high among anaemic patients. The following table is given below in detail:

\begin{tabular}{|c|c|c|c|c|c|}
\hline \multirow{2}{*}{\multicolumn{2}{|c|}{ Groups }} & \multicolumn{2}{|c|}{ Anaemia } & \multirow[t]{2}{*}{ Total } & \multirow[t]{2}{*}{ Chi-square test value } \\
\hline & & Present & No & & \\
\hline \multirow[t]{2}{*}{ Case } & Observed value $(\mathrm{O})$ & 55 & 43 & \multirow[t]{2}{*}{98} & \multirow{5}{*}{5.2} \\
\hline & Expected value (e) & 47 & 51 & & \\
\hline \multirow[t]{2}{*}{ Control } & Observed value $(\mathrm{O})$ & 40 & 60 & \multirow[t]{2}{*}{100} & \\
\hline & Expected value (e) & 48 & 52 & & \\
\hline \multicolumn{2}{|l|}{ Total } & 95 & 103 & 198 & \\
\hline
\end{tabular}

Table-6: Relationship of anaemia with post-operative wound infection

Here degree of freedom $=($ row -1$) \times($ Column -1$)$

$$
\begin{aligned}
& =(2-1) \times(2-1) \\
& =1
\end{aligned}
$$

In Table-7 shows relationship of obstructed labour/prolonged labor with wound infection where
Chi-square test value 5.6 indicates $\mathrm{p}$ value is less than 0.05 . Thus post caesarean section wound infection rate is significantly high among anaemic patients suffering

\begin{tabular}{|c|c|c|c|c|c|}
\hline \multicolumn{2}{|l|}{ Groups } & \multicolumn{2}{|c|}{ Obstructed labor/ prolonged labor } & \multirow[t]{2}{*}{ Total } & \multirow[t]{2}{*}{ Chi-square test value } \\
\hline & & Yes & No & & \\
\hline \multirow[t]{2}{*}{ Case } & Observed value $(\mathrm{O})$ & 32 & 66 & \multirow[t]{2}{*}{98} & \multirow{5}{*}{5.63} \\
\hline & Expected value (e) & 24.74 & 73.25 & & \\
\hline \multirow[t]{2}{*}{ Control } & Observed value $(\mathrm{O})$ & 18 & 82 & \multirow[t]{2}{*}{100} & \\
\hline & Expected value (e) & 25.25 & 74.74 & & \\
\hline \multicolumn{2}{|l|}{ Total } & 50 & 148 & 198 & \\
\hline
\end{tabular}
from obstructed or prolonged labor. The following table is given below in detail:

Table-7: Relationship of obstructed labour/prolonged labor with wound infection

Here degree of freedom $=($ row -1$) X($ Column -1$)$

$$
\begin{aligned}
& =(2-1) \times(2-1) \\
& =1
\end{aligned}
$$

In Table- 8 shows association of premature of membrane and post caesarean section wound infection where Chi-square test value 5.7 indicates $\mathrm{p}$ value is less

\begin{tabular}{|c|c|c|c|c|c|}
\hline \multicolumn{2}{|l|}{ Groups } & Patients with PROM & Patient without PROM & Total & The Chi-square test value \\
\hline \multirow[t]{2}{*}{ Case } & (O) & 35 & 63 & \multirow[t]{2}{*}{98} & \multirow{5}{*}{5.7} \\
\hline & (E) & 29.7 & 68.3 & & \\
\hline \multirow[t]{2}{*}{ Control } & (O) & 25 & 75 & \multirow[t]{2}{*}{100} & \\
\hline & (E) & 30.3 & 69.7 & & \\
\hline Total & & 60 & 138 & 198 & \\
\hline
\end{tabular}
than 0.05 . Thus association of premature rupture of membrane with wound infection rate is statistically significantly. The following table is given below in detail:

Table-8: Association of premature of membrane and post caesarean section wound infection 
Here degree of freedom $=($ row -1$) \times($ Column -1$)$

$$
\begin{aligned}
& =(2-1) \times(2-1) \\
& =1
\end{aligned}
$$

In Figure-5 shows distribution of patients by indication of LUCS where among the 98 patients who develop wound infection following LUCS, most common indication for operation was obstructed labour $(32.65 \%)$, followed by foetal distress $(26.53 \%)$. The following figure is given below in detail:

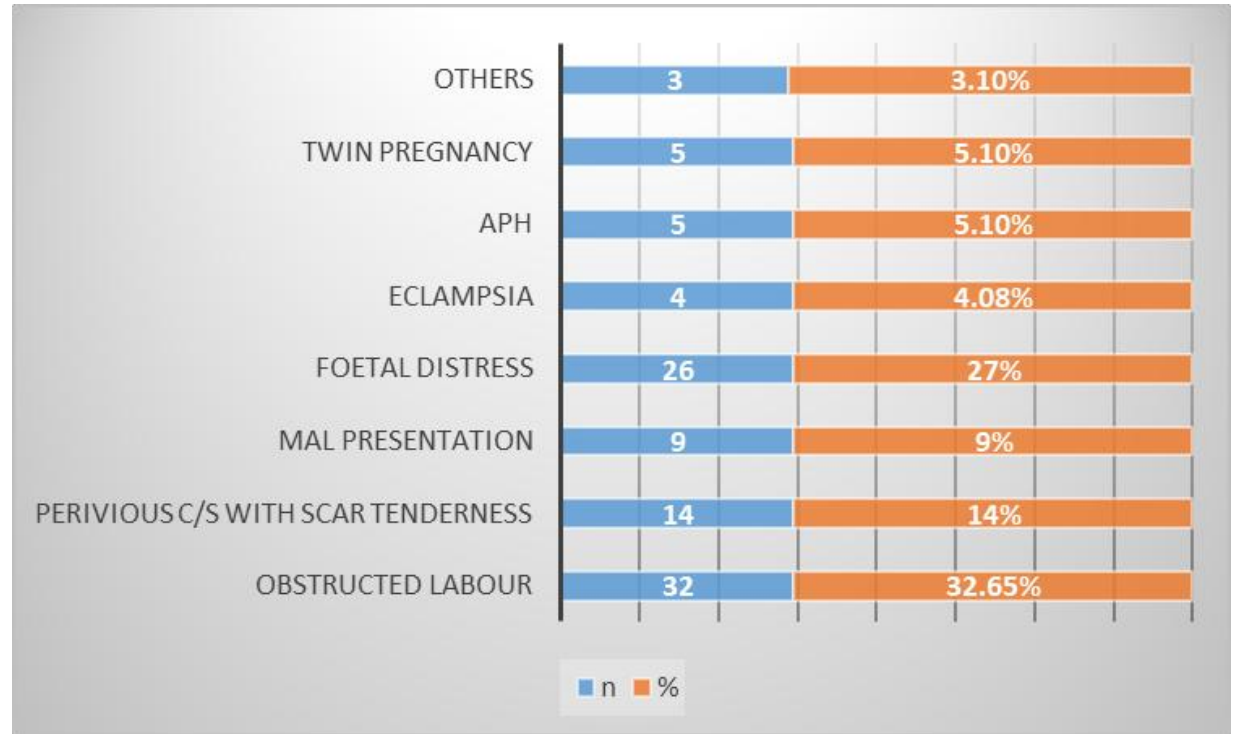

Fig-5: Distribution of patients by indication of LUCS

In Figure-6 shows time of presentation of wound infectionwhere among 98 patients 40 940.8\%) patients faced $7^{\text {th }}$ OPD. The following figure is given below in detail:

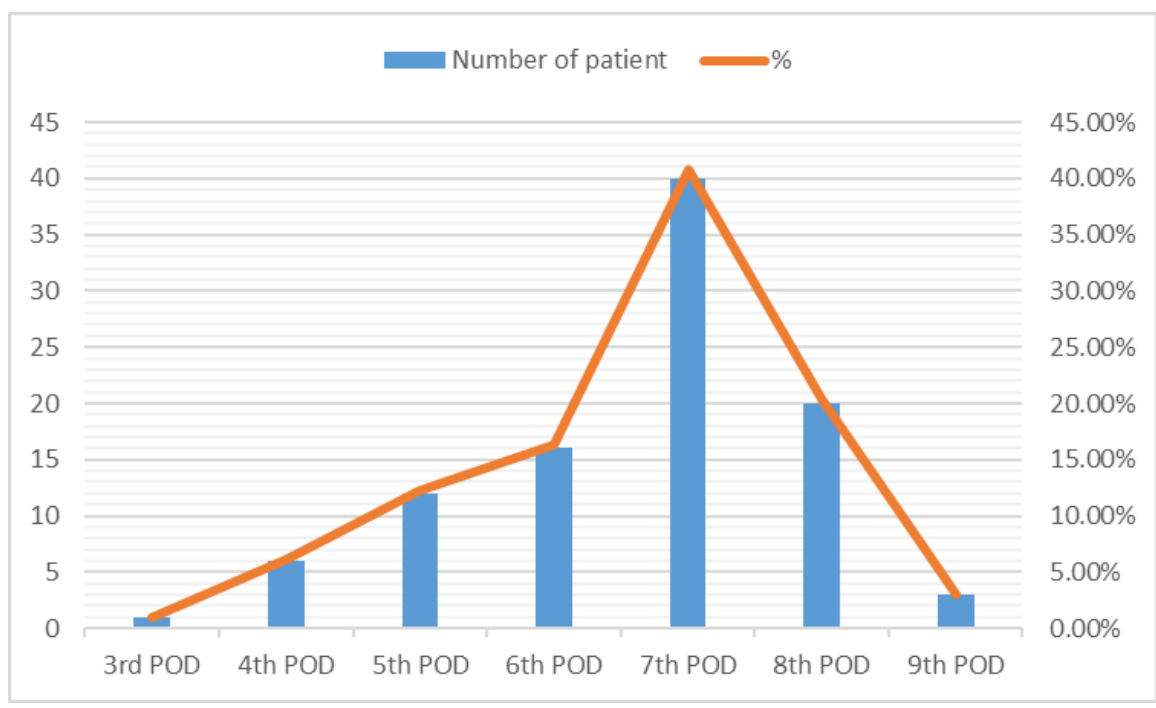

Fig-6: Time of presentation of wound infection

In Figure-7 shows types of wound infection where most $(78.6 \%)$ of wound infections involved only skin or subcutaneous tissue of the incision. In $20.4 \%$ cases infection involved deep soft tissue of the incision.
In one case pus came out through the drain and it was considered as organ/space infection. The following figure is given below in detail: 


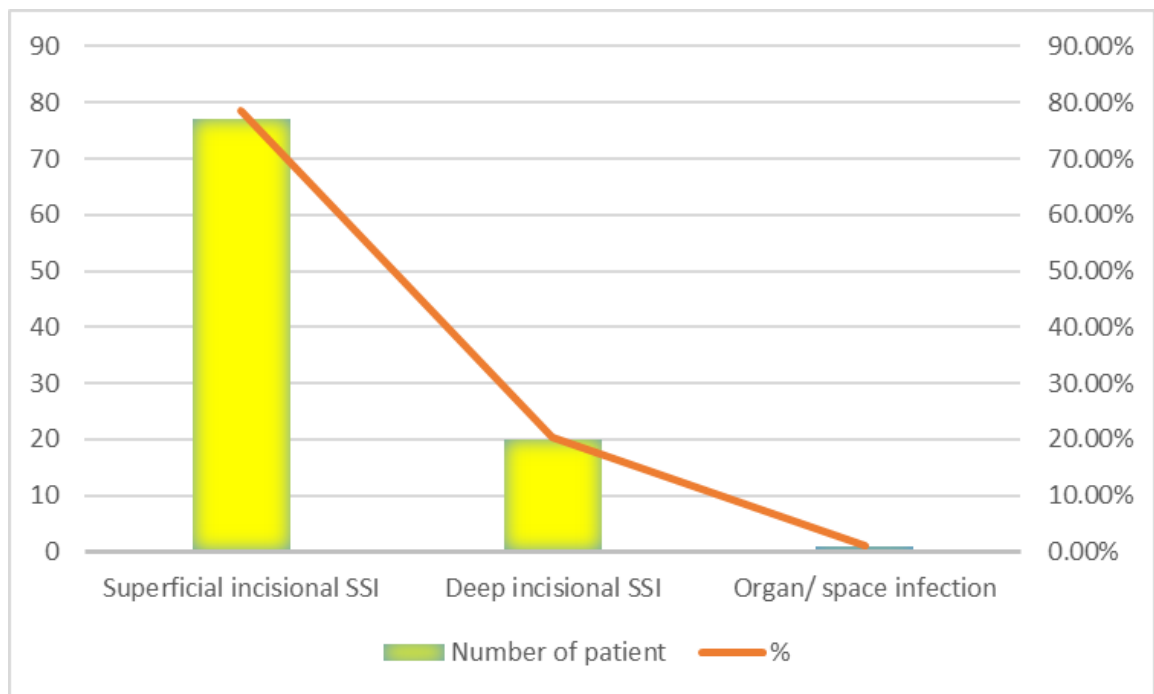

Fig-7: Types of wound infection

In Table-9 shows Nature of wound discharge and organisms where half of the patients in this study discharged thick creamy pus from their wound. In $58 \%$ cases the wound was infected by Staphylococcus aureus. E. coli is the second most common (30.6\%) culprit for post caesarean section wound infection.

Table-9: Nature of wound discharge and organisms

\begin{tabular}{|l|l|l|l|}
\hline Nature of discharge & Organisms & $\mathbf{N}$ & $\mathbf{\%}$ \\
\hline Serosanguinous & Staphylococcus aureus & 9 & $9.2 \%$ \\
\hline Thick creamy pus & Staphylococcus aureus & 49 & $50 \%$ \\
\hline Muddy thin odourless & E. coli & 30 & $30.6 \%$ \\
\hline Blue green pus & Pseudomonas & 2 & $2.0 \%$ \\
\hline Yellow fishy odour & Klebsiella pneumonia & 4 & $4.1 \%$ \\
\hline No specific nature & Proteus & 4 & $4.1 \%$ \\
\hline
\end{tabular}

In Figure-8 shows Total hospital stay required in patients who developed wound infection where average hospital stay in the control group was 6 days. Whereas infected group has to remain in the hospital for longer period, with average hospital stay of 18 days. Thus wound infection leads to additional hospital stay of 12 days on an average the following figure is given below in detail:

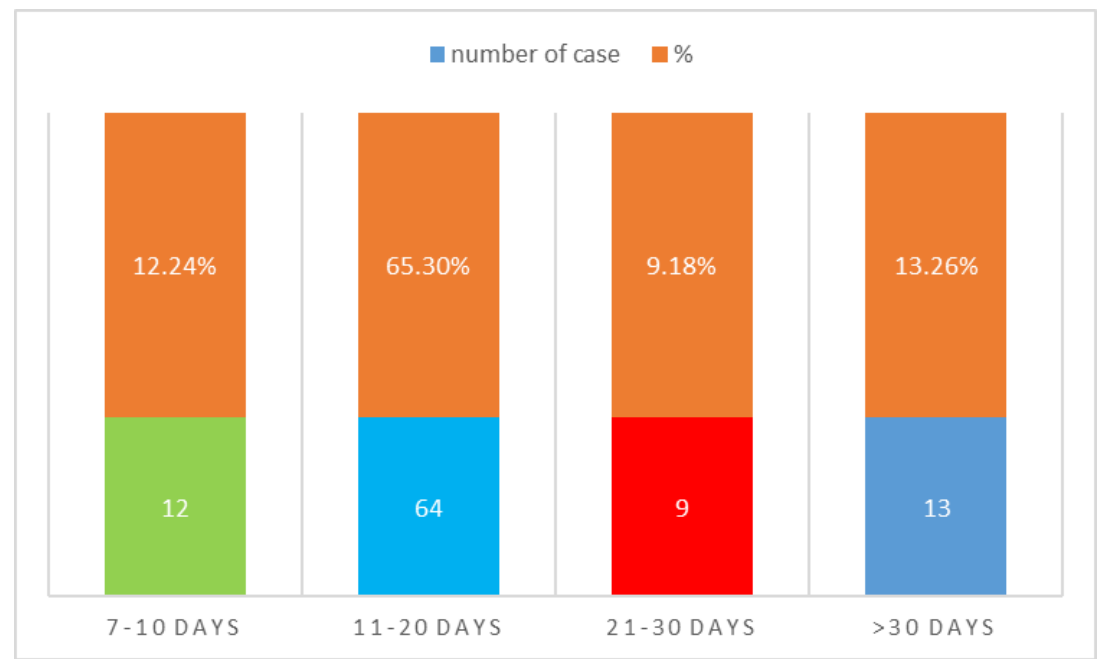

Fig-8: Total hospital stay required in patients who developed wound infection

In table-10 shows further management required for wound healing where for control of infection and healing of wound, all patient required regular dressing. According to culture and sensitivity reports antibiotic was changed in $85(86.7 \%)$ patients. Secondary suture was given in $86(87.75 \%)$ patients. 
Table-10: Further management required for wound healing

\begin{tabular}{|l|l|l|}
\hline Further treatment & Number of cases & Percentage (\%) \\
\hline Daily dressing & 98 & 100 \\
\hline Change of antibiotics & 85 & 86.73 \\
\hline Blood transfusion & 9 & 9.18 \\
\hline Secondary suture & 86 & 87.75 \\
\hline Mass closure & 3 & 3.06 \\
\hline
\end{tabular}

\section{Discussion}

This descriptive observational type of study was carried out with an aim to evaluate the post emergency caesarean section wound infection regarding risk factors, the causative organisms and their antibiotic sensitivity.

Above table shows that in the study period 4200 delivery were conducted in RMCH. Among them $1050(25 \%)$ baby were delivered by caesarean section.

After caesarean section $98(9.3 \%)$ patients develop wound infection. If post discharge wound infection would be considered than the rate will be much higher. Caesarean section surgical site infection surveillance conducted by one study found wound infection in $11.7 \%$ patient [5].

In this study most of the post caesarean wound infection occurred at reproductive age group of 15-34 years with peak incidence at mid 2nd decade of life. One study Aziz in 1997 in Bangladesh also made similar observation. The infection rate is more in primigravida than multigravida in our study.

Regarding socio-economic condition majority was middle class which was $78.6 \%$.

In this study all but one wound infection occurred following emergency caesarean section. Statistical analysis using the chi-square test had shown significantly $(\mathrm{p}<0.05)$ higher incidence of wound infection following emergency intervention. Similar findings were reported in some other studies.

This study shows that $9.2 \%$ and $5 \%$ patients are diabetic in case group and control group respectively. The higher percentage of diabetic patient in the case group is statistically significant $(\mathrm{p}<0.05)$.

In this study $56 \%$ patients in case group were anaemic. In comparison $40 \%$ patients in control group were anaemic this difference indicates an association between anaemia and wound infection.

In this study wound infection rate is significantly lower in patients having regular ante natal checkup. Inother study found that $<7$ antenatal visit was associated with infection [6].
This is the single most important factor where intervention is mostly effective \& by good antenatal care we can avoid many risk factors like anemia, obstructed labour, prolonged labour, and we can avoid many of emergency caesarean section also.

In this study, $32(33 \%)$ and $18(18 \%)$ patient had suffered from obstructed prolonged labour prior to caesarean section in case and control group respectively. This finding indicates significant association of wound infection with obstructed labour with a $\mathrm{p}$ value of less than 0.05 .

In this study, $32(33 \%)$ and $18(18 \%)$ patient had suffered from obstructed /prolonged labour prior to caesarean section in case and control group respectively. This finding indicates significant association of wound infection with obstructed labour with a $\mathrm{p}$ value of less than 0.05 .

Premature rupture of membrane occurred in $35.7 \%$ patients in wound infection group and in $25 \%$ of patients in control group. This higher incidence of PROM in wound infection group is statistically significant with $\mathrm{p}$ value less than 0.05 . In one study also supports these findings. Following membrane rupture, the amniotic fluid is no longer sterile and may act as a transport medium by which bacteria come into contact with the uterine and skin incisions [6]. Research has identified an association between prolonged rupture of the membranes and an increased risk of SSI."

In this study, most common indication of caesarean section was obstructed labour (32.65\%), followed by foetal distress $(26,53 \%)$ in both case and control group.

In this study the peak incidence of wound infection was found in between 6". 8" post-operative day. Other showed the same result [7].

In this study the appearance of abdominal wound infection was highest at 7 th post-operative day $(50 \%)$ and the average was (Mean+SD- 7.3+1,01 day).Other study showed the largest number of wound infections became clinically evident on the 7 postoperative day and on an average of 6,8 post-operative day [8].

The most of the infected wound showed (50\%) thick creamy pus and the organism isolated is Staphylococcus aureus This study revealed that 
maximum wound infection is due to $\mathrm{S}$. aureus Next common is E. coli. one study reported that among 100 patients 60 had positive wound culture and S. aureus, E. coli, Streptococcus. Pseudomonas and Proteus were the common infective organisms [8].

Other study noted the commonest infective organism in his series is Coliform (60\%) followed by Staphylococcus $(40 \%)$ [9].

In case and control group average hospital stay was 16 days and 6 days respectively. Thus wound infection leads to average additional hospital stay of 10 days. One study estimated that the mean length of extended stay attributable to SSI was 9.8 days [10]

For control of infection and healing of wound, all patients required regular dressing. According to culture and sensitivity reports antibiotic was changed in $85(86.7 \%)$ patients. Blood transfusion was given to 9 patients. Secondary suture was given in $86(87.75 \%)$ patients.

\section{LIMITATION}

- For most accurate result all the patents who did not develop wound infection in the study period should be included in the control. But due to shortage of time and lack of resources only 100 patients were taken as control purposively.

- Have no information regarding intra- and inter practice reproducibility ofmeasurement and recording procedures.

\section{Conclusion}

From our result we can conclude that all pregnant women should have ante natal check up by trained personals also they need Health education - to create awareness in the society about ante natal care \& highlighting the risk factors of pregnancy and delivery. Further study is needed for better outcome.

\section{REFERENCE}

1. Lister J. On a new method of treating compound fractures. Lancel, 1867; 1: 326-329, 387-389, 507509

2. Henderson E, Love EJ. Incidence of hospitalacquired infection associated with caesarean section. J Hosp Infect. 1995; 29:245-255

3. https://www.google.com/search?rlz=1C1GGRV_e nBD810BD810\&tbm=isch\&q=wound +infection $+f$ ollowing+caesarean+section. $\&$ chips $=q$ : wound + inf ection+following+caesarean+section,online_chips: staphylococcus+aureus\&usg=AI4_-

kRxEanmIgMkBqTAEKeGiiPvZqSCUg\&sa=X\& ved=0ahUKEwiUw6HajdTfAhUDfnAKHb2nDKI Q41YIKCgE\&biw=1366\&bih=662\&dpr=1\#imgrc =96vAM9J0oxdH-M:

4. Duff P, Smith PN, and Keiser JF. Antibiotic prophylaxis in low risk caesarean section. J Reprod Med. 1982; 27: 133-138.

5. Johnson A, Young D, Reilly J. Caesarean section surgical site infection Surveillance. Journal of Hospital Infection. 2006:1-6.

6. Kerr JMM. The technic of Caesarean section with special reference to the lower uterine segment incision. Am J Obstet Gynecol. 1926;12:726.

7. Alan HD, Lauren N. Post partum hemorrhage and abnormal puerperium: current obstetric and Gynaecological Diagnosis and Treatment: 9th ed. USA: 2004; 546-47.

8. Balthazar ER, Colt JD, Nichols RL. Preoperative hair removal: a random prospective study of shaving versus clipping. South Med J. Jul 1982;75(7):799-801.

9. Matin ASMR. Wound infection in planned abdominal surgery [dissertation) Dhaka: Bangladesh College of Physicians and Surgeons; 1981.

10. Dipiro JT, Martindale RJ. Infection in surgical patients: effects on mortality hospitalization, and post discharge care. Am J Health System Pharm. 1998; 55(8): 777-81. 